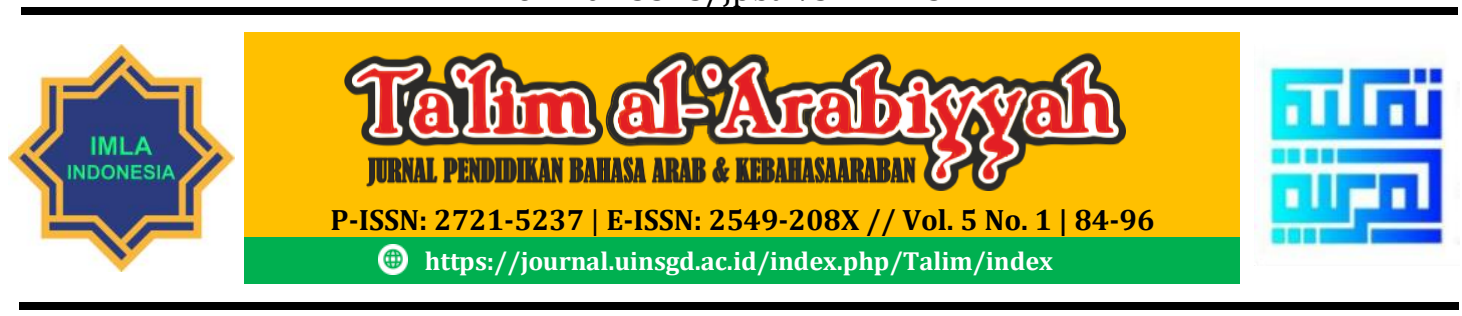

\title{
Typology of Student Learning in Qira'ah Subject with Multiple Intelligence Perspective
}

\author{
Abdul Muid ${ }^{1}$, Aulia Mustika Ilmiani ${ }^{2}$, Ahmad Fikri $^{3}$ \\ ${ }^{1}$ Universitas Jambi, Indonesia \\ ${ }^{2}$ Institut Agama Islam Negeri Palangkaraya, Indonesia \\ ${ }^{3}$ Institut Agama Islam Negeri Kerinci, Indonesia \\ Corresponding E-mail: abdulmuid02@,unja.ac.id
}

\section{ABSTRACT}

This study tries to reveal the typology of student learning in Qira'ah subjects, the Multiple Intelligence of students in these subjects, and the relationship between student learning typology in Qira'ah subjects from the perspective of Multiple Intelligences. The Subjects in this study were students of the Jam'iyah Ihsaniyah al-Mukhtariyah Kerinci Islamic Boarding School. This research uses qualitative and quantitative methods. The results showed that the type of student learning in Qira'ah subjects consisted of Auditory learning types, followed by Visual learning types and some students had Kinesthetic learning styles. The intelligence possessed by students when taking Qira'ah lessons is Linguistic or Verbal intelligence which functions to utilize language to communicate. Visual Intelligence is useful for analyzing facts and realities that are seen directly and Kinesthetic Intelligence to directly capture the material. In the Qira'ah subject at the Jam'iyah Ihsaniah al-Mukhtariyah Kerinci Islamic Boarding School, students' learning styles are closely related to multiple intelligences to develop directed and effective learning abilities and processes.

Keywords: Typology, Qira'ah Learning, Multiple Intellegences

\section{ABSTRAK}

Penelitian ini mencoba mengungkapkan tipologi belajar siswa pada mata pelajaran Qira'ah, kecerdasan ganda yang dimiliki siswa pada mata pelajaran tersebut serta hubungan antara tipologi belajar siswa pada mata pelajaran Qira'ah dilihat dari perspektif kecerdasan Ganda. Objek dalam penelitian ini adalah siswa Pondok Pesantren Jam'iyah Ihsaniah al-Mukhtariyah Kerinci. Penelitian ini menggunakan metode kualitatif dan kuantitatif. Hasil penelitian menunjukkan bahwa tipe belajar siswa pada mata pelajaran Qira'ah terdiri dari tipe belajar Auditori, disusul oleh tipe belajar Visual serta sebagian siswa memiliki gaya belajar Kinestetik. Adapun kecerdasan yang dimiliki oleh siswa ketika mengikuti pelajaran Qira'ah adalah kecerdasan Linguistik atau Verbal yang berfungsi untuk memanfaatkan bahasa untuk berkomunikasi. Kecerdasan Visual yang berguna untuk menganalisis fakta dan realita yang dilihat secara langsung dan Kecerdasan Kinestetik untuk menangkap langsung materi dengan apa yang dilihat. Dalam mata pelajaran Qira'ah di Pondok Pesantren Jam'iyah Ihsaniah al-Mukhtariyah Kerinci, gaya belajar siswa sangat erat kaitannya dengan kecerdasan majemuk untuk mengembangkan kemampuan dan proses pembelajaran yang terarah dan efektif.

Kata Kunci: Tipologi, Pembelajaran Qira'ah, Kecerdasan Ganda 


\section{INTRODUCTION}

In Qira'ab learning, students are required to be able to read and understand Arabic texts after being equipped with Nahwu and Sharaf knowledge. Because basically, Qira'ah is one of the language skills that students must master in this case is a language learner. In the meantime. Qira'ablearning in Arabic is needed as a manifestation container of mastery of Arabic grammar which aims to understand classical books (Turats) and the latest reading written in Arabic (A. A. Rahman 2018).

In language learning, especially Arabic, Qira'ab is one of the third of the four language skills such as listening skills, speaking skills and finally writing skills, These four skills must be mastered by every language learner to be said to be a competent learner in the language(Fauzia, Slamet, and Gunawan 2019). Therefore, every Islamic educational institution such as Islamic boarding schools, madrasa, and other course institutions in which learning Arabic will include Qira' ab as a part of its curriculum (Rile et al. 2015).

Qira'ah learning to date still uses several references from classical books and is still used in Islamic education institutions such as Islamic boarding schools by first mastering the principles of Nahwu and good Sharaf (Makhoul 2017). As for formal institutions such as Madrasah, there is not much study because the Arabic curriculum uses unity theory (Nazhariyatul Wibdah) which means that all language skills are learned in one book, while in boarding schools each competence and language skills are studied separately (Naz̧bariytul Furu ).

Arabic books, especially teaching materials about Qira'ah, are scattered and widely used in Islamic boarding schools, especially in Indonesia, which is generally references to Qira'ah subjects that are commonly used in several Middle Eastern institutions, such as the book Al-Arabiya li-al-Naasyiz by Sheikh Mahmud Ismai, Al'Arabiyah baina Yadaik by Abdurrahman Bin Ibrahim Al-Fauzan, Hikayat Kalilah wa Dimnah by Ibn al-Muqaffa. The books are written in Arabic which is commonly used for Madrasa students in Cairo. And these books are references for Arabic teachers who teach Qira'ah material in Indonesia to date (Ediyani et al. 2020).

In principle, teaching materials are termed materials that can be used and utilized as an effort to improve the quality and quality of learning(Muid et al. 2020). Teaching materials are also unique and specific, with the intention that they can only be used for certain learners in certain learning processes and situations. Whereas specific means that teaching materials can be arranged in such a way only to achieve predetermined targets or goals and the systematic method of delivery of teaching material must also be following the characteristics of the subject and the characteristics of the user, namely students (A. A. Rahman 2018).

With the current development of technology, teaching materials are not only fixed in the form of books or printed books, because in a broader sense the teaching materials also cover the world of technology which can be used as teaching materials. Therefore, clear standards and criteria are needed that can be used as teaching materials. This characteristic is very important to be known by the teacher with the intention of helping students' teaching and learning activities through media or materials that are planned and arranged systematically which functions to achieve completeness in learning according to the previously established criteria and standards. 
Completeness of learning can sometimes be influenced by the typology or learning style of each individual, namely students to build and manage material that has been received and then applied in everyday life with others. This typology gives its characteristics to connect all the ideas, ideas, thoughts, and feelings that are depicted in behavior.

Effective learning must be able to improve the quality of thinking, namely thinking efficiently, innovatively, creatively, and constructively and being able to convey ideas and behave wisely. Besides, good learning must be able to improve thinking attitudes, individual quality and be able to process concepts and knowledge in certain conditions and situations.

Qira'ab learning material for some students is difficult because it requires a good initial mastery of Arabic grammar (Nahwu and Sharf) as well as mastery of a lot of Arabic vocabulary (Ardiansyah and Muhammad 2020). Therefore, to get maximum learning outcomes by the time provided, the teacher must facilitate and study institutions properly and implement appropriate and effective strategies for accelerating understanding of students who have various typologies or learning styles. Learning styles are important to be known by every student to determine the right attitudes and methods to help optimize absorption of learning.

The Islamic boarding school of Jam'iyah al-Mukhtariah Kerinci is one of the oldest Islamic boarding schools in Kerinci Regency, Jambi Province. This Islamic boarding school has two levels, namely Middle (Wustha) and High Level or better known as Madrasah. The students at this boarding school also have various educational backgrounds. In high schools, some students are junior high school graduates who have never had any contact with Qiraah learning before. This should be a concern for teachers to introduce Qiraah as one of the language skills that must be mastered to be able to read and understand Arabic books and texts. With these different educational backgrounds of the students as well as the different family and cultural environments, the typology of learning the students also varied. This certainly has an impact on the achievement of Qiraah's learning objectives. Attention to typology or student learning styles needs to be followed up by accommodating intelligence.

Many studies have been carried out by previous researchers related to qiraah learning such as that carried out by Rifqi Aulia Rahman, who conducted a study on Qiraah Skills and Consideration of Learning Strategies. This study aims to map Qiraah learning strategies and determine their suitability with the language learner stage. The results of the study show that the Qiraah learning strategy has three stages which include: Beginner (mubtadiin), intermediate (mutawassitbin), and advanced (mutaqaddimin). Besides, mapping and strategy determination is also based on several considerations, such as effectiveness, relevance, and efficiency (Rifqi Aulia Rahman, 2018).

Amir Hamzah conducted a study on The Theory of Multiple Intelligences and Its Implications for Learning Management. The results of these studies indicate that Intelligence refers to the ability to solve problems and produce products in various actual situations and conditions. Through this definition, he found that there are at least nine kinds of intelligence possessed by children. This is called the theory of multiple intelligences, namely language, mathematical logic, space, gestures, music, 
interpersonal communication, intrapersonal, naturalistic, and existential. intelligence. The theory of multiple intelligences influences learning orientation. According to this theory, if the teaching materials are introduced according to the outstanding intelligence of students, students will find it easier to understand the lesson. Therefore, teachers need to understand this theory to improve their abilities and make it easier for them to achieve educational goals(Hamzah 2009).

Rizka Widayanti also conducted a study on the Implementation of Arabic Learning based on Multiple Intelligences at Al-Kautsar Elementary School Malang. This paper aims to describe the implementation of Arabic language learning based on multiple intelligences at Al-Kautsar Elementary School Malang. The findings of the study indicate that the implementation of Multiple Intelligence-based Arabic learning can provide an overview of the achievement and diversity of activities carried out by teachers and students in the classroom(Widayanti and Dewi 2020).

Based on the relevant studies above, this study will focus on the concept of typology of student learning which is certainly different from one another, as well as measuring the achievement of Qiraah learning objectives in terms of quality and quantity through the theory of multiple intelligences. Previous research has focused more on mapping Qiraah learning strategies and the role of multiple intelligences in the management of learning as a whole. Therefore, the fundamental difference between the three in this study and its novelty lies in the types of learning models that will be explored by students of Islamic boarding schools when participating in Qiraah learning, which is measured from the perspective of multiple intelligences.

\section{METHOD}

This study uses qualitative and quantitative approaches (mixed method), which aim to find out and explore information in depth about the learning typology of Islamic boarding school students from the subjects reviewed in the Multiple Intelligence Perspective and see how the phenomenon of learning styles and their relationship with their multiple intelligences, as well as knowledge of percentages. types/learning styles of students in their relevance to multiple intelligence. This type of research is descriptive-analytic in the form of field studies which are used to conduct field analysis of the learning types of Islamic boarding schools in Kerinci in the Qira'ah course seen in the perspective of Multiple Intelligence and things related to related sources. Data collection techniques used in this study were observation, interviews, and checklists about student learning phenomena in qira'ah subjects with multiple intelligences.

\section{RESULT AND DISCUSSION}

\section{Typology of Student Learning in Qira'ah Subjects}

Active and creative learning will help the process expected competency development. However, the achievement of learning outcomes is strongly influenced by the learning style of students in following qira'ah subjects which require full readiness to accept and understand every given text regarding everyday expressions(Winarti, Yuanita, and Nur 2019). 
As the results of observations of students in the Qira'ah subject, it appears that they have differences in their attitude towards efforts to increase their understanding. The material presented can accommodate students who have audiolingual and visual learning styles so that it is hoped that learning outcomes can be achieved by ideal competencies. The type of student learning appears during the learning process where gestures, responses, and ways of providing answers to each question asked. The formation of this type of learning cannot be separated from the convenience that each student has when attending lectures in the classroom. Auditory learning styles show their existence by listening carefully to understand every explanation. The visual learning style shows its existence by looking at the image displayed on the LCD.

\section{the Type of Learning of the Jam'iyah \\ Ihsaniah al-Mukhtariah Kerinci Islamic Boarding School students}

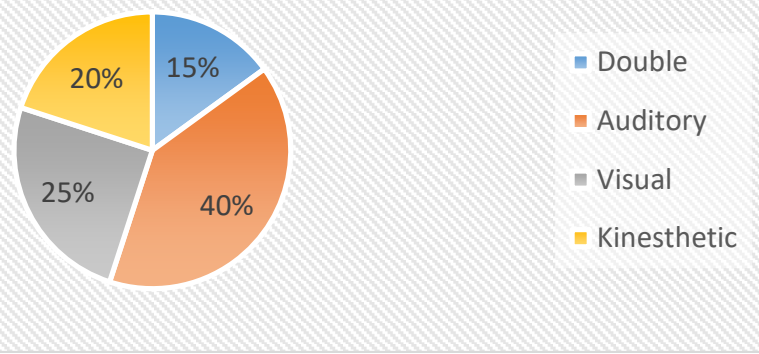

In the chart above, it can be seen that the most dominant type of learning among students is Auditory as much as $40 \%$, this indicates that the lecture or verbal delivery model is more acceptable. Then in the second order, the type of student learning is Visual as much as $25 \%$, this indicates that students are more able to receive the material by presenting images, graphics, examples displayed on the LCD screen or the like so that they can be absorbed better. Meanwhile, the Kinesthetic learning type was $20 \%$, which indicates that the learning model that can be captured by a number of these students is a direct practice that does not only rely on lectures or showing examples .

More than that, there is a double learning type or there is a similarity of two or three types which are equally as much as $15 \%$, this indicates that students who are in this type have a dominant type that is balanced so that two sides of the learning model must be carried out. For example, students will be able to absorb the material if there is a lecture as well as provide examples by showing videos or the like, likewise, there are those who can absorb the material if it is shown while simultaneously practicing it. Therefore, the learning model must be able to accommodate all types of learning that are owned by students. Besides, the method of delivering Qira'ab material is planned with a visual display to accommodate visual learners accompanied by auditory delivery to further improve student understanding. As the results of interviews with students stated that this learning model could help provide an understanding of the Balaghah material which was conveyed straightforwardly and familiarly among the students. 
The implementation of Qira'ab learning requires serious effort in achieving the expected goals as a support for understanding the Arabic scriptures(Mustofa 2011). Because the main purpose of learning qira'ah is to be able to understand the meaning in the reading(Efendi 2005).

The way of learning towards science is not always homogeneous, even heterogeneous where one student will not be uniformly precise to produce an understanding of science. Likewise, for Qira'ah learning, in essence, students are invited to learn the expressions and style of writing language (Uslub) in Arabic books and about the use of the language they use every day which is certainly familiar in their minds.

As the results of observations of students in the Qira'ab subject, it appears that they have differences in their attitude towards efforts to increase their understanding. The material presented can accommodate students who have audiolingual and visual learning styles so that it is hoped that learning outcomes can be achieved by ideal competencies. The type of student learning appears during the learning process where gestures, responses, and ways of providing answers to each question asked. The formation of this type of learning cannot be separated from the convenience that each student has when attending lectures in the classroom. Auditory learning styles show their existence by listening carefully to understand every explanation. The visual learning style shows its existence by looking at the image displayed on the LCD(Bire, Geradus, and Bire 2014).

based on the results of the questionnaire, it can be seen that the most dominant type of learning among students is Auditory as much as $40 \%$, this indicates that the lecture or verbal delivery model is more acceptable. Then in the second order, the type of student learning is Visual as much as $25 \%$, this indicates that students are more able to receive the material by presenting images, graphics, examples displayed on the LCD screen or the like so that they can be absorbed better. Meanwhile, the Kinesthetic learning type was $20 \%$, which indicates that the learning model that can be captured by a number of these students is a direct practice that does not only rely on lectures or showing examples.

\section{Multiple Intelligences of Jam'iatul Ihsaniah Al-Mukhtariyah Kerinci Islamic Boarding School Students in Qira'ah subjects}

Every student has a different intelligence from one another. This can be seen when expressing their understanding in front of other students, some are trying to convey their logic of thinking, some are conveying by looking at the structure of the expressions being exemplified and some are answering to encourage the enthusiasm for learning to their friends who do not understand it.

Besides, a lesson needs to see and monitor the state and type of intelligence possessed by students by identifying it to get optimal learning. As described in the chart regarding the results of the distribution of questionnaires related to multiple types of intelligence to the Jam'iyatul Ihsaniah al-Mukbtariah Kerinci Islamic Boarding School Students as follows: 


\section{Multiple Intelligence Intervals for Students of the Jam'iyatul Insaniah al-Mukhtariah Kerinci Islamic Boarding School}

\begin{tabular}{|c|}
\hline Lingustic \\
\hline Matematic \\
\hline Visual \\
\hline Kinestetic \\
\hline - Musical \\
\hline Interpersonal \\
\hline - Intrapersonal \\
\hline - Natural \\
\hline Esistencial \\
\hline
\end{tabular}

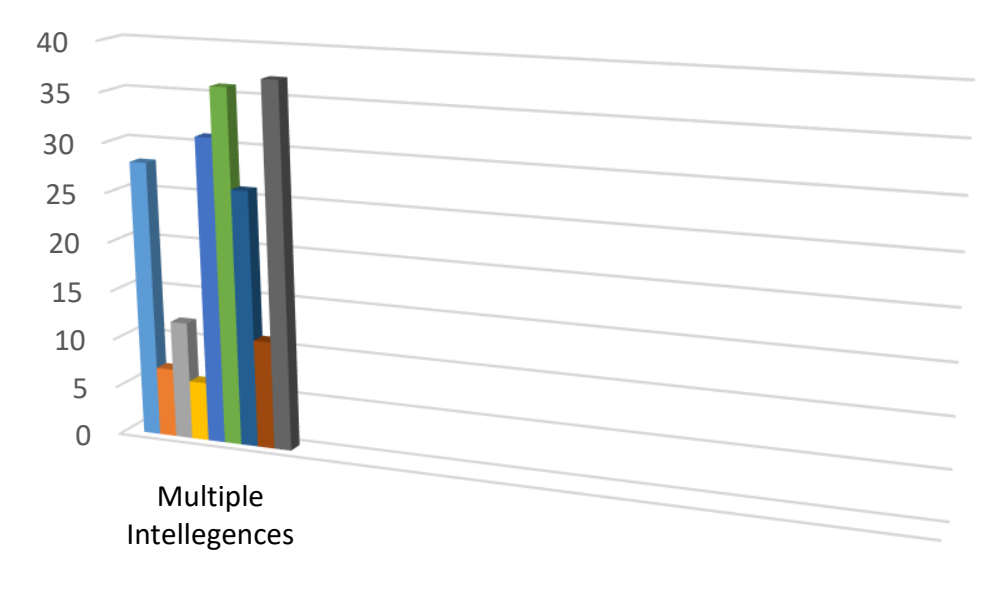

Based on data about intelligence, the most dominant and most students have it is existential intelligence. This intelligence leads students to understand the purpose of their life by using and honing their brains as well as possible. In this case, the willingness to be perceived as existing and wanting recognition to be a priority in every activity and always appearing in front of his friends. Therefore, the desire for recognition from friends and the environment becomes an impetus to always be present in any material presented in the sense of high learning motivation to be able to get and understand the material being studied.

The learning tendencies contained in the students' multiple intelligences need to be channeled into various learning activities to help the process of implementing the desired education. Often learning ignores the principle of student learning needs so that effective and efficient learning outcomes are rarely found (Rohaniyah 2017).

The Qira'ah learning process aims to make students able to understand the contents of the verses of al-Qur'an al-Karim, al-Hadith al-Nabawiyah, and Arabic texts written in the legacy of previous scholars(Asadi, Khateb, and Shany 2017). Therefore, the statements made by Arabic speakers cannot be separated from the need to talk practically about everyday life. Likewise, for Arabic learners in Indonesia, it is necessary to express expressions related to everyday life. Most of the content of Qira'ah is related to everyday conversation, it's just different languages, but some content only exists in Arabic but is not found in Indonesian.

Student intelligence is influenced by the environment in which he lives, studies and plays. Sometimes the environment is not in line with the potential intelligence possessed so that the ability to express cannot be properly channeled(Yavich and Rotnitsky 2020). As found in the classroom, some students have expertise in carving Arabic sentences so they often participate in Arabic Khat or Calligraphy competitions which are useful to accommodate their talents. 
Based on data about intelligence, the most dominant and most students have it is existential intelligence. This intelligence leads students to understand the purpose of their life by using and honing their brains as well as possible. In this case, the willingness to be perceived as existing and wanting recognition to be a priority in every activity and always appearing in front of his friends. Therefore, the desire for recognition from friends and the environment becomes an impetus to always be present in any material presented in the sense of high learning motivation to be able to get and understand the material being studied (Asrori, Thohir, and Ainin 2012).

Interpersonal intelligence ranks second and is almost shared by students. This indicates that the students of the Jam'iyah Ibsaniah al-Mukhtariyah Kerinci Islamic Boarding School have a level of sensitivity and closeness to people around them, especially to their friends. This is what gives rise to a tolerant attitude and cohesiveness in every activity that helps one another. However, sometimes this attitude is not always positive if it is not managed properly, where individual work such as examinations must also be done alone without depending on other people to be carried out and carried out as well as possible (Dolati and Tahriri 2017).

The third intelligence that many students have is musical intelligence, where the habit of singing music or listening to songs becomes a means of helping in understanding a lesson. In general, when the material is presented with musical rhythms with both material content and a translation of the songs played to students, in general, we understand the Qira'ah content in it. As the results of the observation that students know the content of Qira'ah material taught by being shown about the translation of Indonesian songs translated into Arabic or Arabic songs to be sung, so is student participation that is better than not showing the learning process without involving elements this.

The fourth level of intelligence possessed by students is linguistic intelligence, where language skills are characteristic in expressing their ideas and ideas. In the learning area of Qira'ah, it is inseparable from language learning whose content is related to the daily speech styles experienced by students. Meanwhile, the teacher guides or provides everyday examples in the mother tongue to invite students to animate and recognize the material being studied.

The intelligence possessed by students in the fifth-order is intrapersonal intelligence, where the ability to realize everything that is done to live a disciplined and orderly life in living the predetermined conditions. This intelligence shows that awareness in worship is the main element in behavior. Obedience to God will affect awareness in acting both in interaction and in the teaching and learning process. As it is known that most of the students of the Jam'iyah Ihsaniah al-Mukhtariah Kerinci Islamic boarding school, of course, their attitudes and politeness to lecturers are still well preserved as well as in matters of mahdhah worship.

Visual intelligence ranks sixth among the intelligence possessed by students. This intelligence is usually related to a learning style that demands a visual appearance that helps students understand the material. However, this intelligence is only possessed by 12 students, which means that the ability to lift the material visually does not fully assist understanding. This is of course inversely proportional to the verbal or linguistic ability in which the presentation of the material is carried out in an auditory manner which is more dominant in understanding the material. The seventh-order 
intelligence is natural which is only possessed by 11 students. This intelligence is natural for a handful of students because the absorption of the material is related to the observation of nature presented inexact science.

The next intelligence is logical-mathematical intelligence which is only owned by 7 students, which means that most of them do not have this intelligence. This intelligence sees everything based on mathematical calculations that consider logic in thinking such as expressing everything to understand it by thinking mathematically(Gilakjani 2012). For example in the Qira'ah text there is a dialogue related to the use of the word بلى as an answer to justify a question by using the word it نفي it weets mathematically if become أليس كذلك following the rules(Owens 1990):

$$
\text { نفي ات ات اثبات + نفي + نفي }
$$

Students will find it easier to capture material in this way, but this intelligence is minimal for students.

Then the last intelligence and the least frequently possessed by students is kinesthetic intelligence which is only possessed by 6 students. In general, kinesthetic intelligence is not related to language, which demands more verbal intelligence and does not make better movements. It is different from the learning style which requires understanding or memorizing by pacing to make understanding the text easier. Meanwhile, intelligence is what is in the self to grasp everything easier to understand, even though not on a small scale in the classroom.

The differences in multiple intelligence possessed by students of the Jam'iyatul Ibsaniah al-Mukbtariyah Kerinci Islamic Boarding School can have implications for varied learning attitudes as well. As sometimes found in students who are very active in attending lectures and appear to be sitting in front of each piece of material presented, this enthusiasm is unconsciously in line with the intelligence they have. However, sometimes it is found that students seem indifferent to lectures and even carry out other activities such as playing with their cellphones or talking to their friends whose level of intelligence is indirectly inconsistent with the way the material is delivered.

\section{Typology of Learning of the Jam'iyatul Ihsaniah al-Mukhtariyah Kerinci} Islamic Boarding School Students in a Multiple Intelligence Perspective

Student learning types in the Qira'ah subject at Islamic Boarding school of Jam'iyatul Ihsaniah al-Mukhtariah Kerinci are mapped into all types, namely Auditory, Visual and Kinesthetic which have different learning tendencies. The type possessed by this student can be influenced by learning comfort, habits, and the level of multiple intelligence they have. Therefore, in following the Balaghah course, it is required to be able to balance lecture activities and accommodate all types of learning so that the expected learning objectives can be achieved.

Qira'ah learning tends to be done in Auditory and Visual types to understand the various expressions and terms contained in a text. Besides that, Kinesthetic can 
also be done to further strengthen the abilities possessed by students. The suitability of the type of learning with multiple intelligences that settle in the minds of students for follow-up is important to do so that learning objectives run orderly and optimally. Therefore, the following is an overview of the types of learning and multiple intelligences of students:

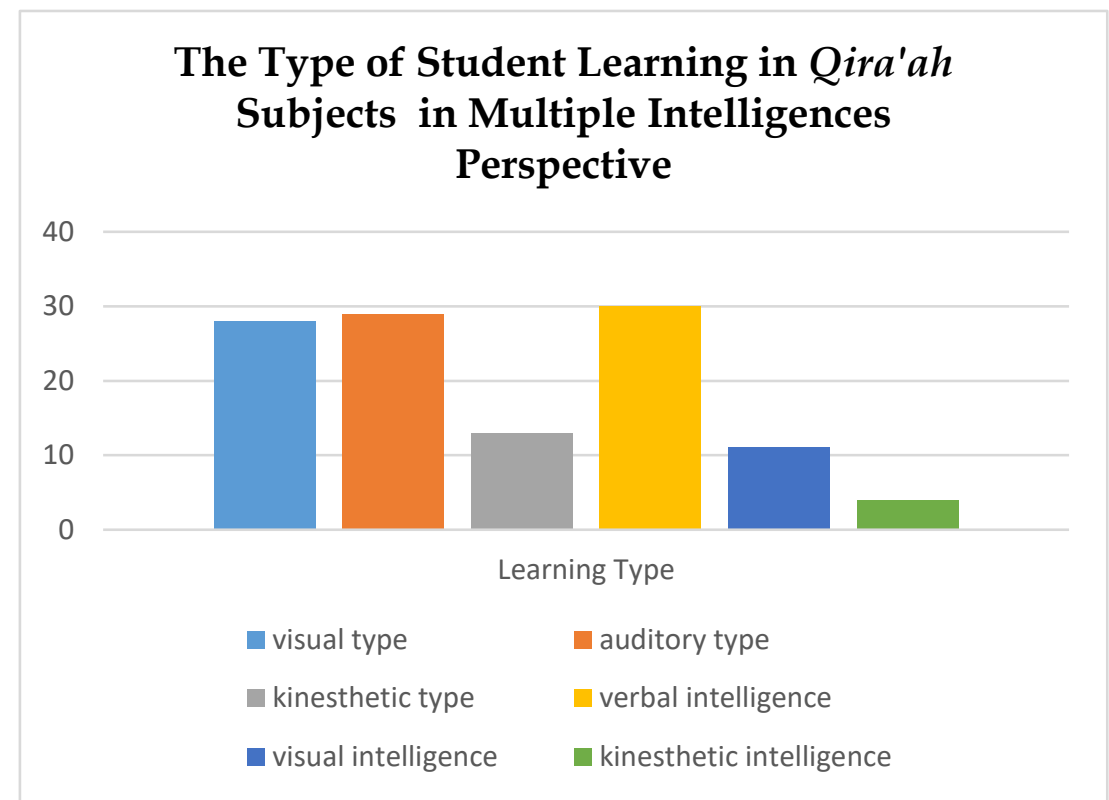

In carrying out the teaching and learning process, teachers are not only required to improve the competence of students, but also the attitudes and skills that contribute to the values of education. The learning style used in Qira'ah learning requires full sincerity for the realization of an understanding of this science as one of the sciences used to understand Arabic books.

The type of learning is sometimes influenced by the level of intelligence possessed by each student so that the maturity of thinking can lead to the formation of a comfortable and focused learning style(Kayalar and Kayalar 2017). Qira'ah Learning does not only require a directed learning process but also requires an appreciation of every expression that is applicable and experienced daily.

The basis for multiple intelligences sometimes needs to be channeled to achieve a learning style that suits their interests. In this case, a teacher needs to carefully select and sort out how to deliver material that is effective and efficient, and thoroughly conveyed to all learners who have different bits of intelligence(Widayanti 2013). Intelligence in capturing material cannot be equated between one student and another, this is because the facilities and potentials possessed by students are not the same so that lecturers must be able to accommodate the intelligence possessed by these students to form optimal learning.

Based on the data collected, it is explained that in general, the type of student learning in the Balaghah course goes hand in hand with the intelligence that should be possessed during the Balaghah learning process. Auditory learning types that dominate student learning styles also have a balance with the verbal intelligence that students should have. This ability shows that language proficiency by processing pure words is obtained from Auditory skills through direct listening to be later verbally expressed. 
Visual intelligence also has a balance with the type of visual learning, which is more able to capture material by showing it and showing it or realizing it to be able to provide a complete picture. This intelligence demands a learning process by seeing or observing patterns and clear examples visually. In Qira'ah learning, visual teaching patterns are also demonstrated with simulations by showing students to practice so that they can be understood by their friends.

Then the kinesthetic intelligence that only a few students have also needed to be considered considering the type of learning related to kinesthetic which requires special handling as well. Although the kinesthetic type is not directly related to learning Arabic, this type is sufficient to provide valuable experience by practicing alone and being understood on your own through teacher assistance who provides sufficient capital and provisions to understand it.

\section{CONCLUSION}

The implementation of Qira'ab learning requires the right concepts and methods to get good learning outcomes. Therefore, the choice of strategy and fulfillment of learning styles must also be considered by the teacher. The results of research that have been carried out by the exposure and data analysis are as follows: the type of student learning in Qira'ah subjects consisted of Auditory learning types, followed by Visual learning types and some students had Kinesthetic learning styles.

The intelligence possessed by students when taking Qira'ah lessons is Linguistic or Verbal intelligence which functions to utilize language to communicate. Visual Intelligence is useful for analyzing facts and realities that are seen directly and Kinesthetic Intelligence to directly capture the material. In the Qira'ab subject at the Jam'iyah Ibsaniah al-Mukbtariyah Kerinci Islamic Boarding School, students' learning styles are closely related to multiple intelligences to develop directed and effective learning abilities and processes.

\section{REFERENCES}

Ardiansyah, Ade Arip and Azhar Muhammad. 2020. "Implementation of Integrative Arabic Grammar (Nahwu \&amp; Sharaf) Curriculum in Islamic Boarding School." Izdihar: Journal of Arabic Language Teaching, Linguistics, and Literature $3(3): 211-28$.

Asadi, Ibrahim A., Asaid Khateb, and Michal Shany. 2017. "How Simple Is Reading in Arabic? A Cross-Sectional Investigation of Reading Comprehension from First to Sixth Grade." Journal of Research in Reading 40:S1-22.

Asrori, Imam, Muhammad Thohir, and Moh Ainin. 2012. "Evaluasi Pembelajaran Bahasa Arab." Malang: Misykat.

Bire, Arylien Ludji, Uda Geradus, and Josua Bire. 2014. "Pengaruh Gaya Belajar Visual, Auditorial, Dan Kinestetik Terhadap Prestasi Belajar Siswa." Jurnal Kependidikan: Penelitian Inovasi Pembelajaran 44(2). 
Ta'lim al-'Arabiyyah : Jurnal Pendidikan Bahasa Arab dan Kebahasaaraban, 5 (1), 2021

Dolati, Zahra and Abdorreza Tahriri. 2017. "EFL Teachers' Multiple Intelligences and Their Classroom Practice.” SAGE Open 7(3):1-12.

Ediyani, Muhammad, Kasful Anwar, Husaini Husaini, Ridha Zuhaimi, and Taufiq Hidayat. 2020. "The Analysis of Arabic Learning Materials in Al-'Arabiyah Baina Yadaik Book with the Principle of Material Development Approach.” Budapest International Research and Critics Institute (BIRCI-Journal): Humanities and Social Sciences $3(2): 965-74$.

Efendi, Ahmad Fuad. 2005. "Metodologi Pengajaran Bahasa Arab.” Malang: Misylkat.

Fauzia, Mutia, Ade Nandang Slamet, and Heri Gunawan. 2019. "PENGGUNAAN TEKNIK PERMAINAN BERBURU TARKIB TERHADAP KEMAMPUAN SISWA DALAM PEMBELAJARAN BAHASA ARAB MATERI TARKIB." Ta'lim Al-A rabiyyah: Jurnal Pendidikan Bahasa Arab \& Kebahasaaraban 3(1):1-13.

Gilakjani, Abbas Pourhossein. 2012. "Visual, Auditory, Kinaesthetic Learning Styles and Their Impacts on English Language Teaching." Journal of Studies in Education 2(1):104-13.

Hamzah, Amir. 2009. “Teori Multiple Intelligences Dan Implikasinya Terhadap Pengelolaan Pembelajaran.” TADRIS: Jurnal Pendidikan Islam 4(2).

Kayalar, Fethi and Filiz Kayalar. 2017. "The Effects of Auditory Learning Strategy on Learning Skills of Language Learners (Students' Views).”

Makhoul, Baha. 2017. "Moving beyond Phonological Awareness: The Role of Phonological Awareness Skills in Arabic Reading Development." Journal of Psycholinguistic Research 46(2):469-80.

Muid, Abdul, Sulhi Muhamad Daud Abdul Kadir, Noza Aflisia, and Neldi Harianto. 2020. "Learning Model of Speaking Arabic: Field Research Based on Constructivism Theory at Al Muhsinin Islamic Boarding School Kerinci." Alsuna: Journal of Arabic and English Language 3(2):140-51.

Mustofa, Syaiful. 2011. Strategi Pembelajaran Bahasa Arab Inovatif. UIN-Maliki Press.

Owens, Jonathan. 1990. Early Arabic Grammatical Theory: Heterogeneity and Standardization. Vol. 53. John Benjamins Publishing.

Rahman, Anwar Abd. 2018. "Keterampilan Membaca Dan Teknik Pengembangannya Dalam Pembelajaran Bahasa Arab." Diwan: Jurnal Bahasa Dan Sastra Arab 3(2):155.

Rahman, Rifqi Aulia. 2018. "KEMAHIRAN QIRĀ'AH DAN KONSIDERASI STRATEGI PEMBELAJARAN." Lisanan Arabiya: Jurnal Pendidikan Babasa Arab 2(1):97-120.

Rile, Luis G., Maria Jade Catalan- Opulencia, Nino M. Decenorio, and Nemia L. Tan. 
Ta'lim al-'Arabiyyah : Jurnal Pendidikan Bahasa Arab dan Kebahasaaraban, 5 (1), 2021

2015. "Multiple Intelligences of Students with Learning Disabilities: Its Implication for Business Curriculum Development in United Arab Emirates." Procedia Economics and Finance 23(October 2014):894-98.

Rohaniyah, Jaftiyatur. 2017. "Integrating Learning Style and Multiple." Jumal Pemikiran Penelitian Pendidikan Dan Sains 5(1):19-27.

Widayanti, Febi Dwi. 2013. "Pentingnya Mengetahui Gaya Belajar Siswa Dalam Kegiatan Pembelajaran Di Kelas." Erudio Journal of Educational Innovation 2(1).

Widayanti, Rizka and Yelfi Dewi. 2020. "Implementation of Arabic Learningbased on Multiple Intelligences at Al-Kautsar Elementary School Malang." AL-FURQAN $5(2): 22-35$.

Winarti, Atiek, Leny Yuanita, and Moh Nur. 2019. “The Effectiveness of Multiple Intelligences Based Intelligences and Science Process Skills of Junior High School Students." Journal of Technology and Science Education 9(2):122-35.

Yavich, Roman and Irina Rotnitsky. 2020. "Multiple Intelligences and Success in School Studies." International Journal of Higher Education 9(6):107-17. 